\title{
RELEVANSI MATA KULIAH TINDAK PIDANA KORUPSI DALAM \\ KURIKULUM FAKULTAS HUKUM UNLA TAHUN AKADEMIK 2018/2019 DENGAN VISI UNLA
}

\author{
oleh \\ Hernawati, RAS
}

\begin{abstract}
ABSTRAK
Kasus korupsi banyak melibatkan para pejabat pemerintah maupun anggota dewan, gratifikasi atau suap untuk meloloskan perijinan Meikarta, untuk memperoleh kontrak kerja sama proyek Independen Power Producer. Mencermati kasus-kasus korupsi, pelakunya adalah orang yang terpandang memiliki kedudukan atau jabatan dan berpendidikan, sehingga perlu diketemukan akar permasalahan yang paling mendasar. Dalam hal penelitian ini, akan ditelaah dari aspek kurikulum perguruan tinggi khususnya. Kurikulum di Fakultas Hukum UNLA, untuk tahun akademik 2018/2019 berlaku kurikulum baru yang berbasis Kerangka Kualifikasi Nasional Indoensia (KKNI) dan Standar Nasional Perguruan Tinggi (SNPT). Dalam kurikulum tersebut pada semester VI terdapat mata kuliah Tindak Pidana Korupsi, bertujuan untuk menghasilkan lulusan yang unggul professional, inovatif dan berkarakter sesuai Visi UNLA. Relevansi mata kuliah tindak pidana korupsi dalam kurikulum Fakultas Hukum dengan visi dan misi UNLA yatitu adanya keterkaitan untuk menghasilkan lulusan yang unggul, profseional, inovatif Dan berkarakter untuk tidak melakukan perilaku yang koruptif sehingga menjadi pemimpin birokrat dan aparat penegak hokum yang bersih dan berwibawa. Upaya Fakultas Hukum menghasilakn lulusan sesuai visi UNLA terkait dengan mata kuliah tindak pidana korupsi yaitu Fakultas Hukum dalam kurikulumnya selalu mengupayakan agar materi tindak pidana korupsi diberikan baik dalam mata kuliah sebagai sisipan atau mata kuliah tersendiri dalam kurikulum baru untuk angkatan 2018/2019 sebagai upaya pencegahan tindak pidana korupsi dengan lulusan selain unggul, potensial, inovatif juga berkarakter sesuai jati diri bangsa Indonesia yang jujur dan dapat dipercaya.
\end{abstract}

\section{PENDAHULUAN}

\section{Latar Belakang}

Kasus korupsi terus datang silih berganti menjadi pemberitaan yang ramai dibahas di media cetak maupun media elektronik. Belum tuntas kasus yang satu, telah ada lagi kasus yang berikutnya membuat publik tidak percaya dengan kasus korupsi yang terjadi. Kasus korupsi banyak melibatkan para pejabat pemerintah maupun anggota dewan, gratifikasi atau suap untuk meloloskan perijinan Meikarta, untuk memperoleh kontrak kerja sama proyek Independen Power Producer.

Pembangunan pembangkit Listrik tenaga Uap Mulu Tambang Riau, ada suap jual beli jabatan di pemerintah Kabupaten Corebon. Kasus korupsi juga mewabah di Komite Olahraga Nasional Indonesia (KONI) terkait dengan dana hibah dari Kemenpora ke KONI.

Kasus terbaru yang menghebohkan terkait dengan jual beli jabatan di Kementerian Agama yang melibatkan politisi PPP. Hari Senin, 18 Maret 2019 KPK menyita seratusan juta rupiah setelah menggeledah ruang Menteri Agama. ${ }^{1}$

Semakin meluas dan maraknya kasus tindak pidana korupsi memerlukan sumber daya manusia yang meningkat pula. Jumlah kasus di KPK 164 pada tahun 2018, Sumber daya manusia di KPK terbatas, yaitu Jaksa 100 orang kebutuhan 150 orang, penyidik 104

\footnotetext{
${ }^{1}$ Republika Selasa, 12 Maret 2019, hlm. 1
} 
orang kebutuhan 1.000 orang penyidik. Menurut Ketua KPK Agus Rahardjo, bahwa KPK telah meminta perwakilan dari berbagai Lembaga Negara untuk menjadi penyidik, permintan itu dikirim pada Badan Pengawasan Keuangan dan Pembangunan (BPKP), Pusat Pelaporan dan Analisis Transaksi Keuangan (PPATK), otoritas Jasa Keuangan (OJK) dan Penyidik Pegawai Negeri Sipil (PPNS), Kementerian Lingkungan Hidup dan Kehutanan. ${ }^{2}$ Keberadaan penyidik dari berbagai intsansi membuat kasus yang diatngani lebih bervariasi.

Mencermati kasus-kasus korupsi, pelakunya adalah orang yang terpandang memiliki kedudukan atau jabatan dan berpendidikan, sehingga perlu diketemukan akar permasalahan yang paling mendasar. Dalam hal penelitian ini, akan ditelaah dari aspek kurikulum perguruan tinggi khususnya.

Menindaklanjuti Peraturan Menteri Riset Teknologi Dan Pendidikan Tinggi Nomor 53 Tahun 2019 Tentang Penyelenggaraan Pendidikan Anti Korupsi di Perguruan Tinggi yang antara lain mengetahui bahwa pendidikan merupakan proses pembelajaran dan pembentukan perilaku yang diselenggarakan pada perguruan tinggi berkaitan dengan pencegahan perilaku koruptif dan tindak pidana korupsi.

Selanjutnya menurut Pasal 2 Permen tersebut dinyatakan bahwa peendidikan anti korupsi wajib diselenggarkan melalui mata kuliah berupa sisipan atau insersi pada mata kuliah wajib umum (MKWU) atau mata kuliah yang relevan. Selain melalui mata kuliah berdasarkan Pasal 3 Permen diatas, pendidikan anti korupsi dapat diselenggarakan melalui kegiatan kemahasiswaan dan atau kegiatan pengkajian. Kegiatan kemahasiswaan terdiri atas kegiatan kokurikuler, kegiatan ekstrakurikuler dan kegiatan unit kemahasiswaan. Kegiatan pengkajian terdiri atas pusat kajian dan pusat studi.

Banyaknya kasus korupsi sangat memprihatinkan. Kasus korupsi tahun 2017 berdasarkan modus yang sering dilakukan oleh pelaku korupsi dan ditangani oleh penegak hukum adalah penyalahgunaan anggaran, namun nilai kerugian negara paling besar terjadi pada modus penyalahgunaan wewenang yang merugikan keuangan negara. ${ }^{3}$ Kasus korupsi Tahun 2017 berdasarkan modus yaitu ${ }^{4}$ :

1. Penyalahgunaan Anggaran :

Kasus Korupsi : 154 kasus

Kerugian : Rp. 1,2 triliun

2. Mark up

Kasus Korupsi : 77 kasus

Nilai Kerugian Negara : 1,8 triliun

3. Pungutan Liar

Kasus Korupsi : 71 kasus

Nilai Kerugian Negara : Rp. -

4. Penyalahgunaan Wewenang

Kasus Korupsi : 61 kasus

Nilai Kerugian Negara : Rp. 2,3 triliun

5. Laporan Fiktif

Kasus Korupsi : 56 kasus

Nilai Kerugain Negara : Rp. 616 triliun

6. Kegiatan/Proyek Fiktif

Kasus Korupsi : 54 kasus

Nilai Kerugian Negara : Rp. 227 miliar

${ }^{2}$ Ibid.hlm.2

${ }^{3}$ Anti Korupsi.Org, 30 Desember 2019

${ }^{4}$ Ibid 
7. Penggelapan :

Kasus Korupsi : 44 kasus

Nilai Kerugian Negara : Rp. 187 miliar

8. Suap

Kasus Korupsi : 42 kasus

Nilai Suap : Rp. 211 miliar

9. Penyunatan/pemotongan

Kasus Korupsi : 10 kasus

Nilai Kerugian Negara : Rp. 3,9 miliar

10. Pemerasan

Kasus Korupsi : 3 kasus

Nilai Pemerasan : Rp. 189 miliar

11. Mark Down

Kasus Korupsi : 2 kasus

Nilai Kerugian Negara : Rp. 41,7 miliar

Hasil survey Tranpasrency International menunjukkan Indeks Persepsi Korupsi (IPK) Indonesia berada di level 38 dari skala $0-100$ pada 2018. Indeks mendekati 0 mengindikasikan masih terjadi banyak korupsi, seblaiknya makin mendekati 100 semakin bersih dari korupsi. Dengan skor tersebut Indonesia berada di peringkat 89 dari 180 negara yang disurvei.

Berdasarkan data Indonesia Corruption Watch (ICW), aparat penegak hukum sebagai ujung tombak dalam upaya pemberantasan korupsi telah menangani 454 kasus sepanjang 2018. Penindakan kasus korupsi yang dilakukan oleh penegak hukum dalam empat tahun (2015-2018) mengalami penurunan. Baik dalam jumlah kasus maupun aktor yang ditetapkan sebagai tersangka. Rata-rata kasus dugaan korupsi yang ditangani penegak hukum periode 2015-2018 sebanyak 392 kasus dengan jumlah tersangka mencapai 1.153 orang dan kerugian negara sebesar Rp. 4,17 triliun per tahun. Adapun penindakan terbanyak dicatat pada 2017, yakni mencapai 576 kasus aktor sebagai tersangka 1.298 orang.

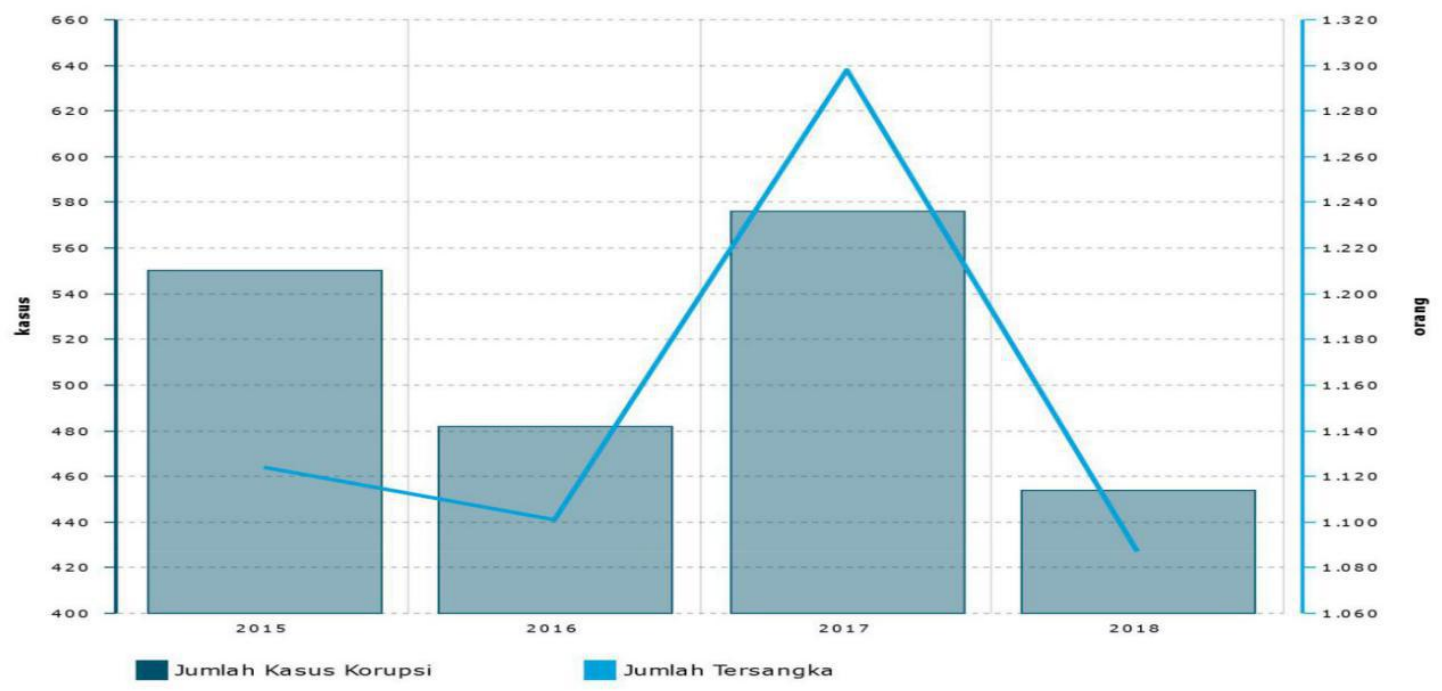


Kurikulum di Fakultas Hukum UNLA, untuk tahun akademik 2018/2019 berlaku kurikulum baru yang berbasis Kerangka Kualifikasi Nasional Indoensia (KKNI) dan Standar Nasional Perguruan Tinggi (SNPT). Dalam kurikulum tersebut pada semester VI terdapat mata kuliah Tindak Pidana Korupsi, bertujuan untuk menghasilkan lulusan yang unggul professional, inovatif dan berkarakter sesuai Visi UNLA.

Kurikulum berasal dari bahasa latin yaitu currere (verb) artinya berlari dan curricula (noun) artinya jarak yang harus ditempuh dalam suatu perlombaan. ${ }^{5}$ Dengan demikian kurikulum sebagai pedoman yang terencana untuk mencapai tujuan pendidikan.

(1) Planning

Terdapat empat fungsi yang dapat digunakan dalam penyusunan kurikulum, yakni :

(2) Organizing

(3) Staffing

(4) Controlling 6

Muatan kurkulum sebagai penentu arah pendidikan karakter. ${ }^{7}$

\section{Identifikasi Masalah}

Berdasarkan uraian tersebut di atas, maka selanjutnya dapat dirumuskan permasalahan sebagai berikut :

1. Bagaimana relevansi mata kuliah Tindak Pidana Korupsi dalam kurikulum fakultas hukum tahun Akademik 2018/2019 dengan visi UNLA ?

2. Bagiamana upaya Fakultas menghasilkan lulusan sesuai Visi UNLA terkait dengan mata kuliah tindak pidana korupsi?

\section{TINJAUAN PUSTAKA}

\section{Tindak Pidana Korupsi}

Kata korupsi berasal dari bahasa latin corruption atau corruptus guga dari bahasa latin yang lebih tua yaitu corrumpere, Bahasa Inggris corruption, corrupt, Perancis coorupratio, dan Bahasa Belanda corruption. Di Malaysia resuah diambil dari Bahasa Arab risywah (suap). ${ }^{8}$

Tindak pidana korupsi berdasarkan Pasal 2 dan 3 Undang-Undang Nomor 31 Tahun 1999 tentang Pemberantasan Tindak Pidana Korupsi jo Undang-undang Nomor 20 Tahun 2001 tentang Perubahan Atas Undang-undang Nomor 31 Tahun 1999 Tentang Pemberantasan Tindak Pidana Korupsi berbunyi sebagai berikut :

(1) Setiap orang yang secara melawan hukum melakukan perbuatan memperkaya diri sendiri atau orang lain atau suatu korporasi yang dapat merugikan keuangan Negara atau perekonomian Negara, dipidana dengan pidana penjara seumur hidup atau pidana penjara seumur hidup atau pidana penjara paling singkat 4 (empat) tahun dan paling lama 20 (dua puluh) tahun dan denda paling sedikit Rp. 200.000.000,00 (dua ratus juta rupiah) dan paling banyak Rp. 1.000.000.000,00 (satu milyar rupiah).

(2) Dalam hal tindak pidana korupsi sebagaimana dimaksud dalam ayat 10 dilakukan dalam keadaan tertentu pidana mati dapat dijatuhkan.

\footnotetext{
${ }^{5}$ Agustinus Hermino, Manajemen Kurikulum Berbasis Karakter, Konsep, Pendekatan Dan Aplikasi, Alfabeta, Bandung, 2014, hlm. 30

${ }^{6}$ M. Indadun Rahmat, Guru Berkarakter Untuk Implementasi Pendidikan Karakter, Gajah Mada Yogyakarta, 2014, hlm. 33

${ }^{7}$ Ibid, hlm. 29

${ }^{8}$ Ruslan Renggang, Hukum Pidana Khusus, Memahami Delik-delik Di Luar KUHP, Prenadamedia Grup Jakarta 2016, hlm. 60
} 
Pasal 3 berbunyi sebagai berikut :

"setiap orang yang dengan tujuan menguntungkan diri sendiri atau orang lain atau suatu korporasi, menyalahgunakan kewenangan, kesempatan atau sarana yang ada padanya karena jabatan atau kedudukan yang dapat merugikan keuangan Negara atau perekonomian negara, dipidana dengan pidana penjara seumur hidup atau pidana penjara paling singkat 1 (satu) tahun dan paling lama 20 (dua puluh) tahun dan atau denda paling sedikit Rp. 50.000.000,- (lima puluh juta rupiah) dan paling banyak Rp. 1.000.000.000,00 (satu milyar rupiah)."

Menurut Marwan Mas ${ }^{9}$, korupsi terjadi di Indonesia karena hal berikut ;

a. Sistem yang keliru

Perlu perbaikan atas sistem administrasi pemerintahan dan pelayanan masyarakat yang kondusif terhadap terjadinya korupsi;

b. Gaji yang rendah membuka peluang terjadinya korupsi;

c. Law enforcement tidak berjalan;

d. Hukuman yang ringan;

Undang-undang pemberantasan korupsi mengatur ancaman pidana mati, tetapi harus memiliki syarat tertentu, ancaman pidana seumur hidup, denda yang besar, serta ancaman membayar pengganti sejumlah uang yang dikorupsi, tetapi kalau tidak mampu dibayar dapat diganti (subsidair) dengan hukuman penjara yang ringan (Pasal $18 \mathrm{UU}$ Pemberantasan Tindak Pidana Korupsi). Hal tersebut tidak memberikan efek jera atau rasa takut bagi yang lain.

e. Tidak ada keteladanan pemimpin;

f. Masyarakat yang apatis;

Pemerintah mengeluarkan Peraturan Pemerintah Nomor 88 Tahun 1999 yang menempatkan masyarakat sebagai eleman penting dalam pemberantasan korupsi. KPK membentuk Deputi Bidang Pengawasan Internal dan pengaduan masyarakat yang antara lain bertugas menerima dan memproses laporan dari masyarakat.

Guna mencegah perbuatan korupsi diperlukan peningkatan pengawasan internal dengan sistem zikzak, yatitu adanya pengawasan di sektor instansi dan adanya kontrol masyarakat. ${ }^{10}$

Tindak pidana korupsi merupakan kejahatan luar biasa, didasarkan kepada latar belakang bahwa korupsi tidak hanya merugikan keuangan Negara tetapi juga telah merupakan pelanggaran terhadap hak-hak sosial Dan ekonomi masyarakat secara luas. ${ }^{11}$ Maraknya pembangunan infrastruktur di berbagai wilayah di Indonesia ternyata juga menjadi pintu masuknya bagi kepala daerah melakukan praktek tindak pidana korupsi, baik berupa gratifikasi maupun negoisasi rahasia dengan calon penyedia barang dan jasa. ${ }^{12}$ Adanya kegiatan pembangunan infrastruktur yang berakibat tindak pidana korupsi sangat merugikan keuangan Negara. Survei Global Competiviness Report tahun 2019 menunjukkan infrastruktur merupakan komponen penyumbang peningkatan tertinggi sebesar 62,7 persen atau mengalami peningkatan dari tahun sebelumnya sebesar 66,8 persen. ${ }^{13}$ Praktik korupsi dalam infrastruktur sangat mendukung karena adanya

${ }^{9}$ Marwan Mas dalam, ibid, hlm. 63-64

10 Monang Siahaan, Pembaruan Hukum Pidana Indonesia, Grasindo Jakarat, hlm. 116

11 Eri Satriana \& Dewi Kania Sugiharti, Asset RecoveryDalam Pengembangan Hukum Pidana Nasional, Kenimedia Bandung 2019, hlm. 1

12 Andre Notohamijono, Darurat Korupsi Infrastruktur, Republika, Sabtu 23 Nopember 2019, hlm.

${ }^{13}$ Ibid 
persekongkolan antara penguasaha Dan aparat birokrasi.Dalam prakteknya persekongkolan bisa dalam 2 (dua) bentuk,yaitu ${ }^{14}$ :

1) Birokrat memberi referensi kepada pihak pnegusaha untuk mendapatkan modal dan memberi fasilitas pendukung.

2) Birokrat memberi surat sakti untuk memonopoli suatu produksi beserta wilayah pemasarannya.

Proses pengadaan barang dan jasa pemerintah paling potensial untuk korupsi. Sebagian besar kasus korupsi yang ditangani KPK terkait hal tersebut. Meningkatnya anggaran juga mendorong praktik korupsi dengan berbagai bentuknya. ${ }^{15}$ Menurut Centre of Interntional Crime Prevention Dan Law Office For Drug Control and Crime Prevention, ada 10 (sepuluh) bentuk korupsi, yaitu ${ }^{16}$ :

1. Pemberian suap/sogok (Bribery)

Pemberian dalam bentuk uang, barang, fasilitas Dan janji untuk melakukan atau tidak melakukan sesuatu perbuatan yang akan berakibat membawa untung terhadap diri sendiri atau pihak lain, yang berhubungan dengan jabatan yang dipegangnya pada saat itu.

2. Penggelapan (Embezzlement)

Perbuatan mengambil tanpa hak oleh seorang yang telah diberi kewenangan untuk mengawasi Dan bertanggung jawab penuh terhadap barang milik negara oleh pejabat publik ataupun swasta.

3. Pemalsuan (Fraud)

Suatu tindakan atau perilaku untuk mengelabui orang lain atau organisasi, dengan maksud untuk keuntungan Dan kepentingan dirinya sendiri ataupun orang lain.

4. Pemerasan (Extartion)

Memaksa seseorang untuk membayar atau memberikan sejumlah uang atau barang atau bentuk lain sebagai ganti dari seseorang pejabat publik untuk berbuat atau tidak berbuat sesuatu. Perbuatan tersebut dapat diikuti dengan ancaman fisik atau kekerasan.

5. Penyalahgunaan Jabatan atau Wewenang (Abuse of discreation)

Mempergunakan kewenangan yang dimiliki untuk melakukan tindakan yang memihak atau pilih kasih kepada kelompok ataupun perseorangan. Sementara bersikap diskriminatif terhadap kelompok atau perseorangan lainnya.

6. Pertentangan Kepentingan/Memilki usaha sendiri (Internal trading)

Melakukan transaksi publik dengan menggunakan perusahaan milik pribadi atau keluarga, dengan cara memeprgunakan kesempatan dan jabatan yang dimilikinya untuk memenangkan kontrak pemerintah.

7. Pilih kasih (Favoritism)

Memberikan pelayanan yang berbeda berdasarkan alasan hubungan keluarga, afiliasi partai politk, suku, agama Dan golongan yang bukan kepada alasan objektif seperti kemampuan, kualitas, rendahnya harga Dan profesianlisme kerja.

8. Menerima komisi (Commission)

Pejabat public yang menerima sesuatu yang bernilai, dalam bantuan uang, fasilitas, barang dan lain-lain sebagai syarat untuk memperoleh pekerjaan atau hubungan bisnis dengan pemerintah.

9. Nepotisme (Nepotism)

\footnotetext{
${ }^{14}$ Rocky Marbun, Persekongkolan Tender Barang/Jasa, Pustaka Yustisia Yogyakarta 2010, hlm. 13.

15 Andre Notomijoyo., loc.it

${ }^{16}$ Centre For Drug Control And Crime Prevention dalam Rocky Marbun., op.cit, hlm. 98-100
} 
Tindakan untuk mendahulukan sanak keluarga, kawan dekat, anggota partai politk yang sepaham dalam penunjukan atau pengangkatan staf, panitia pelelangan atau pemilihan pemenang lelang.

10. Kontribusi atau sumbangan Illegal (Illegal)

Hal ini terjadi apabila partai politik atau pemerintah yang sedang berkuasa pada waktu itu menerima sejumlah dana sebagai suatu kontribusi dari hasil yang dibebankan kepada kontrak-kontrak pemerintah.

Beragam bentuk atau modus tndak pidana korupsi sehingga penegakan hukumnya banyak melibatkan aparat penegak hukum ada yang penanganan oleh kepolisian, kejaksaan Dan juga oleh Komisi Pemberantasan Korupsi. Tetapi pengembalian kerugian keuangan Negara belum menunjukkan angka yang signifikan atau proporsional, sebagaimana nampak dalam tabel dibawah ini :

TABEL

DATA PENANGANAN PERKARA TINDAK PIDANA KORUPSI PADA KEJAKSAAN RI (2016-2018)

\begin{tabular}{|c|c|c|c|c|}
\hline Kejaksaan RI & 2016 & 2017 & $\begin{array}{c}\text { s.d. } \\
\text { Nopember 2018 }\end{array}$ & Jumlah \\
\hline $\begin{array}{c}\text { Tindak Pidana } \\
\text { Korupsi Kasus Telah } \\
\text { Inkrah }\end{array}$ & 1.819 & 1.672 & 965 & 4.456 \\
\hline $\begin{array}{c}\text { Kerugian keuangan } \\
\text { negara (Rp.triliun) }\end{array}$ & 0.949 & 414 & 0.678 & 6.027 \\
\hline $\begin{array}{c}\text { Pengembalian Uang } \\
\text { Negara (Rp. triliun) }\end{array}$ & 0.349 & 0.734 & 0.522 & 1.605 \\
\hline
\end{tabular}

Sumber : Kejaksaan Agung RI

Data menunjukkan kerugian Negara keuangan Negara akibat tindak pidana korupsi tidak sebanding dengan pengembalian uang Negara.

Dari kasus tindak pidana korupsi yang sudah inkrah dihitung mulai dari tahun 2016 kerugian keuangan Negara 0,449 (Rp. triliun) pengembalian uang Negara hanya 0,349 (Rp.triliun). Tahun 2017 kerugian keuangan Negara 4,4 (Rp.triliun) tetapi pengembalian uang Negara hanya 0,734 (Rp. triliun) dan tahun 2018 sampai dengan bulan November kerugian Negara 0,678 (Rp.triliun), pengembalian uang Negara hanya 0,522 (Rp.triliun). Meskipun ini hanya data dari Kejaksaan Agung RI belum dari KPK, tetapi data tersebut juga telah dapat menunjukkan bahwa penegakan hukum dalam tindak pidana korupsi tidak atau belum sesuai dengan yang diharapkan karena kerugian Negara masih sedikit yang dapat dikembalikan.

\section{Unggul. Profesional, Inovatif dan Berkarakter}

Unggul diartikan lebih dari yang lain memiliki daya saing yang tinggi mampu berkompetisi atau bersaing dengan yang lain. Profesi adalah pekerjaan yang dilandasi pendidikan, keahlian tertentu (keterampilan, kejujuran dan sebagainya). ${ }^{17}$ Menurut Muhammad Nuh ${ }^{18}$ seorang profesional harus memiliki kepribadian sosial sebagai berikut :

1. Bertanggung jawab atas semua tindakan;

2. Berusaha selalu meningkatkan ilmu pengetahuannya;

17 Departemen Pendidikan dan Kebudayaan RI, Kamus Besar Bahasa Indonesia, Jakarta Balai Pustaka 1991, hlm. 789

${ }^{18}$ Muhammad Nuh Dalam Mardani, Etika Profesi Hukum, Rajawali Pers Depok 2017, hlm. 91-92 
3. Mengembangkan pikiran untuk memajukan keterampilan/kemahiran dan keahlian serta pengetahuan profesi.

4. Menjungjung tinggi kepercayaan orang lain terhadap dirinya;

5. Menggunakan saluran yang baik dan benar serta legal dan halal untuk mengatakan ketidakpuasannya;

6. Kesediaan bekerja untuk kepentingan asosiasi, organisasi dan senantiasa memenuhi kewajiban organisasi profesinya;

7. Mampu bekerja dengan baik dan benar tanpa pengawasan tetap atau terus menerus;

8. Mampu bekerja tanpa pengarahan terperinci;

9. Tidak mengorbankan orang lain/pihak lain demi kemajuan/keuntungan diri pribadinya semata;

10. Setia pada profesi dan rekan seprofesi;

11. Setia pada profesi dan rekan seprofesi;

12. Merasa bangga pada profesinya;

13. Memiliki motivasi penuh untuk lebih mengutamakan kepentingan masyarakat yang dilayaninya;

14. Jujur, tahu akan kewajiban dan menghormati hak pihak/orang lain;

15. Segala pengalamannya senantiasa diniati dengan niat dan itikad yang baik, pencapaian tujuan yang hanya ditujukan untuk yang baik. Demikian pula tata cara mencapai tujuan itu dengan cara yang baik.

Lulusan selain unggul, profesional juga harus inovatif. Inovatif adalah menciptakan sesuatu yang belum pernah ada menjadi ada atau menciptakan sesuatu yang sama sekali berbeda. Kreatifitas dalam proses inovasi merupakan pembangkitan ide yang menghasilkan penyempurnaan efektivitas dan efesiensi pada suatu sistem. ${ }^{19}$

Karakter lulusan juga menjadi perhatian utama selain faktor diatas, agar dapat amanah menjalankan tugas, harus jujur dan dapat dipercaya untuk meminimalisir kasus tindak pidana korupsi. Pendidikan karakter merupakan keniscayaan dalam upaya menghadapi berbagai tantangan pergeseran karakter yang dihadapi saat ini. ${ }^{20}$ Pendidikan karakter menenkankan pada keteladanan, penciptaan lingkungan Dan pembiasaan melalui berbagai tugas keilmuan dan kegiatan kondusif. ${ }^{21}$

\section{PEMBAHASAN}

Tindak pidana korupsi saat ini makin meningkat baik kualitas maupun kuantitasnya. Hal tersebut menunjukkan bahawa penegakan hokum terhadap kasus tindak pidana korupsi belum sepenuhnya berhasil menekan atau meiminmalisir kasus tindak pidana korupsi. Setiap hari selalu saja ada pemberitaan mengenai adanya temuan-temuan kasus baru yang tertangkap tangan melakukan suap atau gratifikasi atau praktik korupsi lainnya.

Meningkatnya tindak pidana korupsi akan memiliki resiko sistemik, yaitu kegagalan dan hilangnya kepercayaan kepada penegak hokum. Ketika ada yang ketangkap tangan, hal tersebut tidak menimbulkan keengganan pelaku untuk berbuat korupsi. Sanksi pidana dalam Undang-undang Tindak Pidana Korupsi tidak membuat pelaku malu untuk berbuat praktik korupsi. Sehingga pemberitaan tentang kasus-kasus korupsi baru yang

\footnotetext{
${ }^{19}$ Google.com diakses 2 april 2019, jam 11.35

${ }^{20}$ Kokom Komalasari \& Didin Saripudin, Pendidikan KArakter Konsep Dan Aplikasi Living Values Education, Rafika Aditama Bandung, 2017, hlm. 1

${ }^{21}$ E. Mulyasa, Manajemen Pendidikan Karakter, Bumi Aksara, Jakarta 2016, hlm. 9
} 
bermunculan bukan lagi merupakan hal yang tidak wajar. Perilaku pelaku korupsi sangat merajalalela terlebih dalam pembangunan infrastruktur menumbuhsuburkan adanya praktik korupsi. Untuk melancarkan usahanya pelaku tidak segan lagi melanggar Undang-undang.

Kasus korupsi pada tahun 2017 yang terbanyak adalah penyalahgunaan anggaran dengan kerugian Negara Rp.1,2 triliun Dan mark up sebesar 77 kasus dengan nilai kerugian Negara Rp. 1,8 triliun.tahun 2015-2018 menurut data hasil Survei Transprancy International yaitu 392 kasus, jumlah tersangka 1.153 orang Dan kerugian keuangan Negara sebesar Rp.4,17 triliun pertahun.

Berdasatkan data yang berhasil diperoleh, maka peneliti mengapresiasi adanya Permen riset Teknologi Dan Pendidikan Tinggi Nomor 53 Tahun 2019 Tentang Penyelenggaran Pendidikan Anti Korupsi di Perguruan Tinggi, karena mahasiswa adalah asset bangsa calon penerus pemimpin atau aparat penegak hukum yang bersih dan berwibawa bebas dari perilaku korupsi yang merugikan keuangan negara.

Hal tersebut sejalan pula dengan visi universitas yang ingin menghasilkan lulusan yang unggul, profesional, inovatif dan berkarakter. Kemudian menghadapi masalah korupsi ini juga telah diparesiasi oleh Fakultas Hukum UNLA dalam kurikulumnya yang beberapa mata kuliah menjelaskan tentang tindak pidana korupsi. Dalam kurikulum baru merupakan mata kuliah tersendiri tidak digabung dengan materi tindak pidana lainnya.

\section{Relevansi Mata Kuliah Tidnak Pidana Korupsi Dalam Kurikulum Fakultas Hukum UNLA dengan Vsi UNLA}

Visi merupakan ajuan masa depan, cita-cita yang ingin dilakukan, visi dijadikan panutan gambaran atas situasi dan karakteristik mengenai arah kemana tujuan yang ingin dicapai lulusan Fakultas Hukum agar selaras dengan visi UNLA yaitu menghasilakn lulusan yang unggul, professional, inovatif dan berkarakter.

Kurikulum yang diberikan di Fakultas Hukum untuk para mahasiswa disusun sedemikian rupa, terencana, terstruktur sistematis, mengalami perubahan disesuaikan dengan kebutuhan pasar dan keingginan pengguna lulusan atau stakeholder. Kaitannya dengan mata kuliah tindak pidana korupsi yang diberlakukan untuk tahun akademik 2018/2019 sejalan dengan Peraturan Menteri, Riset, teknologi dan Pendidikan Tinggi Nomor 33 Tahun 2019 Tentang Penyelenggaraan Pendidikan Anti Korupsi di Perguruan Tinggi.

Materi mengenai tindak pidana korupsi telah diberikan pada mata kuliah Delik Khusus yaitu materi diberikan untuk materi UAS/Ujian Akhir Semester tetapi hanya diberikan dua (2) pertemuan karena dibagi lagi dengan materi delik khusus diluar KUHP selain tindak pidana korupsi. Juga materi kuliah Tindak Pidana Pencucian Uang (TPPU), Penyalahgunaan Narkotika ataupun Tindak Pidana Perdagangan Orang (TPPO).

Mata kuliah Kapita Selekta Hukum Pidana juga diberikan materi kuliah mengenai tindak pidana korupsi, tetapi itu juga masih sumier hanya dua (2) pertemuan karena ada materi lain yang terseleksi yang sedang update misalnya cyber crime atau bulliying.

Analisis peneliti materi kuliah tindak pidana korupsi tidak detail karena tidak dijadikan mata kuliah tersendiri masih bergabung dengan materi tindak pidana khusus lainnya. Dalam kurikulum Tahun Akademik 2018/2019, mata kuliah tindak pidana korupsi dijadikan mata kuliah wajib, mata kuliah mandiri tidak digabung materinya dengan materi tindak pidana khusus lainnya, tentu hal ini akan memberikan bobot yang lebih banyak, materi lebih komprehensif menegani tindak pidana korupsi dari aspek hukum pidana materiil, aspek hukum pidana formil penegakan hukum.

Faktor penyebab dan upaya menanggulangi dan analisis kasus-kasus tindak pidana korupsi yang sedang terjadi atau sedang ditangani oleh aparat penegak hukum. Mahasiswa 
sebagai agen perubahan daam pembangunan diharapkan mampu merubah perilaku yang inkonsisten, tidak bertanggung jawab menjadi perilaku yang kondusif mengerti permasalahan-permasalahan yang dihadapi bangsa Indonesia saat ini yaitu antara lain pemberantasan korupsi yang sudah semakin sistematis, merambah ke semua lini tentu diperlukan aparat penegak hukum, birokrat, aparat sipil negara yang professional, inovatif dan berkarakter sebagaimana diamanatkan oleh visi universitas. Lulusan Fakultas Hukum (alumni) diharapkan menjadi contoh atau teladan karena telah dibekali ilmu yang bermanfaat, mendukung upaya pemberantasan tindak pidana korupsi.

\section{Upaya Fakultas Hukum Mengahasilkan Lulusan Sesuai Visi UNLA Terkait Dengan Mata Kuliah Tindak Pidana Korupsi}

Fakultas Hukum secara berkesinambungan terus mengupayakan lulusan/alaumni yang unggul mampu bersaing dengan lulusan dari Perguruan Tinggi Swasta (PTS) atau bahkan dari Perguruan Tinggi Negeri (PTN). Selain membekali ilmu dalam proses belajar di kelas, menganalisis kasus-kasus yang sedang update, terutama khusus untuk mahasiswa semester 4 (empat) ke atas, diikutsertakan dalam perlombaan secara nasional misalnya dalam lomba persidangan semu arbitrase di Jakarta pada tahun 2019, juga mengikuti seminar atau workshop dalam dan luar UNLA untuk menambah kelimuan, juga praktik di Pengadilan mengamati dan membuat laporan kasus dan khusus untuk semester 7 (tujuh) juga melakukan praktek persidangan semu, baik kasus tindak pidana umum ataupun kasus tindak pidana khusus yaitu kasus tindak pidana korupsi dan sebelum penulisan hukum tugas akhir diwajibkan mengikuti kuliah kerja lapangan ke Lembaga Pemasyarakatan, khusus untuk kasus tindak pidana korupsi dapat dlakukan ke Lembaga Pemasyarakatan Sukamiskin Bandung.

Berbekal ilmu secara teori dan praktek diharapkan lulusan mampu mengembangkan pikiran untuk memajukan keterampilan/kemahiran dan keahlian serta pengetahuannya sehingga professional sesuai keahlian di bidang hukum. Terkait dengan mata kuliah yang memuat materi "tindak pidana korupsi", diharapkan mahasiswa mampu membentuk perilaku yang dapat mencegh perilaku koruptif dari tindak pidana korupsi. Lulusan mempunyai gambaran yang utuh tentang bahayanya perilaku tindak pidana korupsi selain bertentangan dengan norma hukum yang berlaku merugikan keuangan negara dapat membahayakan perekonomian negara juga perbuatankorupsi tidak sesuai dengan karakter bangsa Indonesia yaitu jujur dan dapat dipercaya.

\section{PENUTUP}

\section{Kesimpulan}

Relevansi mata kuliah tindak pidana korupsi dalam kurikulum Fakultas Hukum dengan visi dan misi UNLA yatitu adanya keterkaitan untuk menghasilkan lulusan yang unggul, profseional, inovatif Dan berkarakter untuk tidak melakukan perilaku yang koruptif sehingga menjadi pemimpin birokrat dan aparat penegak hokum yang bersih dan berwibawa.

Upaya Fakultas Hukum menghasilakn lulusan sesuai visi UNLA terkait dengan mata kuliah tindak pidana korupsi yaitu Fakultas Hukum dalam kurikulumnya selalu mengupayakan agar materi tindak pidana korupsi diberikan baik dalam mata kuliah sebagai sisipan atau mata kuliah tersendiri dalam kurikulum baru untuk angkatan 2018/2019 sebagai upaya pencegahan tindak pidana korupsi dengan lulusan selain unggul, potensial, inovatif juga berkarakter sesuai jati diri bangsa Indonesia yang jujur dan dapat dipercaya. 


\section{Saran}

Kurikulum bermuatan materi pencegahan tindak pidana korupsi seyogyanya diberikan di semua Fakultas mengapresiasi Permen Dikti tentang Penyelenggaraan Pendidikan Anti Korupsi di Perguruan Tinggi.

Upaya pencegahan tindak pidana korupsi juga seyogyanya diberikan kepada masyarakat melalui penyuluhan hukum agar pencegahan anti korupsi sinergi dengan masyarakat atau pengusaha.

\section{DAFTAR PUSTAKA}

\section{Buku :}

Agustinus Hermino, Manajemen Kurikulum Berbasis Karakter, Konsep, Pendekatan Dan Aplikasi, Alfabeta, Bandung, 2014,

M. Indadun Rahmat, Guru Berkarakter Untuk Implementasi Pendidikan Karakter, Gajah Mada Yogyakarta, 2014

Ruslan Renggang, Hukum Pidana Khusus, Memahami Delik-delik Di Luar KUHP, Prenadamedia Grup Jakarta 2016

Monang Siahaan, Pembaruan Hukum Pidana Indonesia, Grasindo Jakarta

Eri Satriana \& Dewi Kania Sugiharti, Asset RecoveryDalam Pengembangan Hukum Pidana Nasional, Kenimedia Bandung 2016

Andre Notohamijono, Darurat Korupsi Infrastruktur, Republika, Sabtu 23 Nopember 2019, Rocky Marbun, Persekongkolan Tender Barang/Jasa, Pustaka Yustisia Yogyakarta 2010

Centre For Drug Control And Crime Prevention dalam Rocky Marbun

Sumber : Kejaksaan Agung RI tahun 2016 s/d 2018 dalam Eri Sutriana dan Dewi Kania Sugiharti,

Muhammad Nuh Dalam Mardani, Etika Profesi Hukum, Rajawali Pers Depok 2017, okom Komalasari \& Didin Saripudin, Pendidikan KArakter Konsep Dan Aplikasi Living Values Education, Rafika Aditama Bandung,

E. Mulyasa, Manajemen Pendidikan Karakter, Bumi Aksara, Jakarta 2016

H. Salim \& Erlies Septiana Nurbani, Penerapan Teori Hukum Pada Penelitian Tesis dan DIsertasi, Rajawali Press Jakarta, 2013

Peter Mahmud Marzuki, Penelitian Hukum, Jakarta Kencana 2009 Muslan Abdurrahman, Sosiologi Dan Metode Penelitian Hukum, Malang, UMM Press 2009

I Made Paseh Pinantah, Metodologi Penelitian Hukum Normatif Dalam Justifikasi Teori Hukum, Kencana Jakarta 2017

\section{B. Peraturan perundang-undangan}

- Undang-undang Nomor 17 tahun 2007 tentang RPJPN 2005-2025

- $\quad$ TAP MPR No. II/MPR/1978 tentang Ekaprasetia Pancakarsa

\section{Lain-lain :}

- antikorupsi.org

- katadata.co.id 